\title{
Decomposed Buriti Stem and Nitrogen Application Rates on the Growth of Eugenia dysenterica DC (Myrtaceae) Seedlings
}

\author{
Wéverson Lima Fonseca ${ }^{1}$, Augusto Matias de Oliveira ${ }^{2}$, Tiago de Oliveira Sousa ${ }^{2}$, Alan Mario Zuffo ${ }^{3}$, \\ Râmison Fonseca dos Santos ${ }^{4}$, Rezanio Martins Carvalho ${ }^{5}$, Fernandes Antônio de Almeida ${ }^{6}$, \\ Norberto Matias de Oliveira Neto ${ }^{7}$, Leandro de Oliveira Guerra ${ }^{6} \&$ Tiago Soares Gomes ${ }^{4}$ \\ ${ }^{1}$ Department of Crop Production, Federal University of Ceará, Fortaleza, Ceará, Brazil \\ ${ }^{2}$ Department of Agriculture, Federal University of Vales de Jequitinhonha and Mucuri, Diamantina, Minas \\ Gerais, Brazil \\ ${ }^{3}$ Department of Crop Production, State University of Mato Grosso do Sul, Cassilândia, Mato Grosso do Sul, \\ Brazil \\ ${ }^{4}$ Department of Agriculture, Federal University of Piauí, Bom Jesus, Piauí, Brazil \\ ${ }^{5}$ Department of Phytopathology, Federal Rural University of Pernambuco, Recife, Pernambuco. \\ ${ }^{6}$ Department of Agrarian Sciences, Federal University of Paraíba, Areia, Paraíba, Brazil \\ ${ }^{7}$ Department of Biology, Federal University of Piauí, Bom Jesus, Piauí, Brazil \\ Correspondence: Alan Mario Zuffo, Department of Crop Production, State University of Mato Grosso do Sul, \\ Cassilândia, Mato Grosso do Sul, Brazil. E-mail: alan_zuffo@hotmail.com
}

$\begin{array}{lcc}\text { Received: May 23, } 2019 & \text { Accepted: July 14, } 2019 & \text { Online Published: September 30, } 2019 \\ \text { doi:10.5539/jas.v11n16p187 } & \text { URL: https://doi.org/10.5539/jas.v11n16p187 }\end{array}$

\begin{abstract}
The effects of substrates formulated with different proportions of decomposed buriti stem (Mauritia flexuosa) and the application of nitrogen fertilizer rates in the production of cagaita (Eugenia dysenterica DC.) seedlings were investigated in this study. The treatments were arranged in a completely randomized design, in a $3 \times 5$ factorial: three substrates formulated from different proportions of decomposed buriti stem $(0,25$ and $50 \%)$ with a clay loam soil (Oxisol), and five $\mathrm{N}$ fertilizer rates $\left(0 ; 100 ; 200 ; 300\right.$ and $400 \mathrm{mg} \mathrm{dm}^{-3}$ ), with four replicates. At 60 days after emergence, the plant height, stem diameter, leaf area, root length, dry matter accumulation of shoots, roots, and total, shoot:root dry matter ratio (SRR), height:diameter ratio (HDR), and Dickson quality index (DQI) were measured. The substrate containing soil and decomposed buriti stem in the proportion of 3:1 $(\mathrm{v}: \mathrm{v})$, in association with the application of $\mathrm{N}$ rates from 167 to $190 \mathrm{mg} \mathrm{dm}^{-3}$ is recommended for the production of cagaita seedlings, resulting in positive effects on plant growth and development as reported by higher PH, $\mathrm{SRR}$, and HDR. The application of $154 \mathrm{mg} \mathrm{dm}^{-3}$ of $\mathrm{N}$ resulted in higher DQI of the cagaita seedlings.
\end{abstract}

Keywords: cagaita, organic substrate, nitrogen fertilization

\section{Introduction}

The Cerrado is the second largest biome in Brazil, occupying an area of 204.7 million hectares of Central Brazil and has the highest species biodiversity among all the tropical savannah regions of the world (Sano et al., 2008). In this region, more than twelve thousand plant species were recorded, and approximately eleven thousand are vascular plants (Mendonca et al., 2008). The continuous expansion of the agricultural frontier towards the Cerrado has contributed greatly to the decrease and extinction of several native species of the region, thus losing its representativeness without understanding its full potential (Souza, 2006; Silva, 2015).

Several native Cerrado species have the potential for sustainable economic exploitation. Among these plant species, pequi (Caryocar brasiliense Camb.), marolo (Annona crassiflora Mart.), baru (Dipteryx alata Vog.), macaúba palm (Acrocomia aculeata Jacq.), mangaba (Hancornia speciosa Gomez), cagaita (Eugenia dysenterica DC.) are distinguished by their great economic potential and because they are sources of calories, vitamins, proteins, calcium, phosphorus, iron, among others (Silva et al., 2001).

The E. dysenterica DC. belongs to the family Myrtaceae, subfamily Eugenioideae, tribe Eugeniinae (Mendonça et al., 1998). Cagaita has been widely used by the regional population and is one of the native fruits that has 
suffered most from the extinction of the Cerrado vegetation cover due to the advance of agribusiness in the region (Agostini-Costa et al., 2006). Cagaita trees have high fruit production capacity, and older and larger plants can produce more than two thousand fruits per year (Souza, 2006). The cagaita fruits can be consumed in natura by the local population, or processed into juices, jellies, and ice creams (Martinotto et al., 2008), and constitute an excellent source of antioxidants and bioactive components (Abadio-Finco et al., 2012).

During the seedling production phase of this species, some management factors must be considered, in order to increase the germination rate and to provide faster growth and uniformity of the cagaita plants (Souza et al., 2001). Among these factors, the proper management of fertilization, especially of nitrogen, should be highlighted, since this essential nutrient is directly related to some mechanisms and metabolic processes of the plant, such as photosynthesis, respiration, root development, nutrient absorption, differentiation cellular and growth (Costa et al., 2012). Another factor to be highlighted is the type of substrate used, since the substrate is responsible for nutrient supply, aeration, and water retention, providing conditions for the proper growth and development of the plant root system (Alves et al., 2012). Therefore, the use of alternative materials in the composition of the substrates should be investigated in order to reduce the cost of production of seedlings with fertilization and make this activity accessible to all farmers interested in the production of quality seedlings (Sardinha, 2008).

The decomposed buriti stem (DBS) (Mauritia flexuosa L.) is an important alternative material to be used in the formulation of substrates for the cultivation of several plant species, mainly due to its wide distribution and high potential of use in the southern region of Piauí state (Sousa et al., 2010). Its use in the composition of substrates can be a viable alternative to complement the nitrogen fertilization in the cultivation of cagaita seedlings, thus reducing the costs with the acquisition of mineral fertilizer.

The viability of using decomposed buriti stem in the formulation of substrates for the production of fruit and forest seedlings was confirmed in Dipteryx lacunifera Ducke (Calvacante et al., 2011), Enterolobium contortisiliquum (Vell.) Morong (Sousa et al., 2013) and Azadirachta indica (Oliveira et al., 2016). However, the effect of buriti stem use on growth of cagaita seedlings is still unknown. The objective of this study was to investigate the effects of substrates formulated with different proportions of decomposed buriti stem and nitrogen application rates on the production of cagaita seedlings.

\section{Material and Methods}

The experiment was conducted in a greenhouse at the Agronomic Experimental Station of the Federal University of Piauí (UFPI), in Bom Jesus, Piauí state, Brazil $\left(09^{\circ} 04^{\prime} 28^{\prime \prime} \mathrm{S}, 44^{\circ} 21^{\prime} 31^{\prime \prime} \mathrm{W}\right.$ and altitude of $\left.277 \mathrm{~m}\right)$, from October to November 2015. The regional climate, according to the Köppen classification, is Aw, characterized as tropical, with hot summers and a tendency toward high rainfall levels between October and April, and dry winters, with a dry season between May and September. The mean annual temperature is $26.5^{\circ} \mathrm{C}$, with a mean annual rainfall from 900 to $1,200 \mathrm{~mm}$ (Viana et al. 2002).

The experiment was arranged in a completely randomized design, in a $3 \times 5$ factorial scheme, with four replicates. Treatments consisted of three substrates formulated from different proportions of decomposed buriti stem $(0,25$ and $50 \%)$ with a clay loam soil (Oxisol), and five $\mathrm{N}$ fertilizer rates $(0 ; 100 ; 200 ; 300$ and $400 \mathrm{mg}$ $\left.\mathrm{dm}^{-3}\right)$. The $\mathrm{N}$ rates as urea $(45 \%$ of $\mathrm{N})$ was applied in topdressing at 20 and 40 days after emergence at $50 \%$ of the rate evaluated. The buriti decomposed stem was obtained from the Agrovila Formosa settlement in Redenção do Gurguéia, PI, Brazil. The main chemical properties of the soil are shown in Table 1.

Table 1. Some of the chemical properties of the soil used in the experiment

\begin{tabular}{|c|c|c|c|c|c|c|c|c|c|c|c|}
\hline $\mathrm{pH}$ & $\mathrm{P}$ & $\mathrm{K}$ & $\mathrm{H}+\mathrm{Al}$ & $\mathrm{Al}$ & $\mathrm{Ca}$ & $\mathrm{Mg}$ & $\mathrm{K}$ & SB & CEC & $\mathrm{V}$ & $\mathrm{OM}$ \\
\hline & \multicolumn{2}{|c|}{----- $\mathrm{mg} \mathrm{dm}^{-3}$----- } & ------- & - & - & $\mathrm{mol}_{\mathrm{c}} \mathrm{d}$ & & & & $\%$ & $\mathrm{~g} \mathrm{~kg}^{-1}$ \\
\hline 5.4 & 14.19 & 192.5 & 4.95 & 0.00 & 2.24 & 0.86 & 0.49 & 3.59 & 8.54 & 42.1 & 20.9 \\
\hline
\end{tabular}

Note. $\mathrm{pH}$ in water; $\mathrm{P}$ : phosphorus; $\mathrm{H}+\mathrm{Al}$ : potential acidity; $\mathrm{Al}$ : exchangeable acidity; Ca: calcium; $\mathrm{Mg}$ : magnesium; K: potassium; SB: sum of exchangeable bases; $\mathrm{CEC}$ : cation exchange capacity; V: soil base saturation; and OM: Organic matter.

Seeds of E. dysenterica DC. were extracted from mature fruits collected from trees established in a savannah area of the municipality of Redenção do Gurguéia, Piauí, Brazil $\left(09^{\circ} 29^{\prime} 12^{\prime \prime}\right.$ S, 44 $35^{\prime} 11^{\prime \prime}$ W). Seeds were previously selected considering its size and then sown in black polyethylene bags of $12.5 \times 10.0 \mathrm{~cm}(0.4 \mathrm{~L})$, filled with different substrates formulated from a mixture of decomposed buriti stem and soil. Five buriti seeds 
were sown per container at $2.0 \mathrm{~cm}$ depth, and after the establishment, they were thinned to one plant per container. The seedlings were watered daily to maintain the water content of the substrate close to the water retention capacity.

At 60 days after emergence, the plant height, stem diameter, leaf area, root length, and dry matter accumulation of shoots and roots were measured. Plant height $(\mathrm{PH})$ was determined from the substrate level of the container to the apical meristem with the aid of a millimeter ruler. Stem diameter (SD) was measured using a digital caliper (Clarke-150 mm), with an accuracy of $\pm 0.01 \mathrm{~mm}$. The leaf area (LA) was determined using a leaf area meter (Model LI $3100^{\circ}$, LI-COR, Inc., Lincoln, NE, USA). The root length was measured using a millimeter ruler. The plants then were separated into shoots (stem + leaves), and roots, oven-dried at $65{ }^{\circ} \mathrm{C}$ for three days and weighed for the determination of shoot dry matter (SDM) and root dry matter (RDM). From these measurements were calculated total dry matter (TDM), shoot:root dry matter ratio [SRR; shoot dry matter (g)/root dry matter (g)], height:diameter ratio [HDR; plant height $(\mathrm{cm}) /$ stem diameter $(\mathrm{mm})]$, and Dickson quality index [DQI = TDM/(SRR + HDR)] (Dickson et al., 1960).

The data normality was previously tested by the Shapiro-Wilk test at the $5 \%$ significance level, and then the data were submitted to analysis of variance (ANOVA) using software R version 3.5.1. When significant, the means were compared by the Tukey test at the 5\% probability level. Regression analysis was used for the $\mathrm{N}$ fertilizer rates, and significant equations (F-test; $\mathrm{p} \leq 0.05)$ with the highest coefficients of determination were adjusted. The analysis was performed using SigmaPlot 11.0 software for Windows (Systat Software, Inc., San Jose, CA, USA).

\section{Results}

Analysis of variance reported that the effect of substrates formulated with soil and DBS was significant on plant height, stem diameter, root dry matter, and shoot:root dry matter ratio, while the effect of nitrogen application rates was significant on leaf area, shoot dry matter, root length, root dry matter, and Dickson quality index. Interaction between substrates and $\mathrm{N}$ application rates showed a significant effect on plant height, shoot:root dry matter ratio, and height:diameter ratio (Table 2). The highest value of stem diameter and root dry matter was obtained using the substrate S2, consisting of $75 \%$ soil and $25 \%$ DBS.

Table 2. Summary of variance analysis and average values for plant height (PH), stem diameter (SD), leaf area (LA), shoot dry matter (SDM), root length (RL), root dry matter (RDM), shoot:root dry matter ratio (SRR), height:diameter ratio (HDR), and Dickson quality index (DQI) of Eugenia dysenterica DC. seedlings

\begin{tabular}{llllllllll}
\hline \multirow{2}{*}{ Sources of variation } & \multicolumn{7}{c}{ Mean square or average value } \\
\cline { 2 - 10 } & $\mathrm{PH}^{\mathrm{T}}(\mathrm{cm})$ & $\mathrm{SD}(\mathrm{mm})$ & $\mathrm{LA}^{\mathrm{T}}\left(\mathrm{cm}^{2}\right)$ & $\mathrm{SDM}^{\mathrm{T}}(\mathrm{mg})$ & $\mathrm{RL}(\mathrm{cm})$ & $\mathrm{RDM}(\mathrm{mg})$ & $\mathrm{SRR}^{\mathrm{T}}$ & $\mathrm{HDR}^{\mathrm{T}}$ & $\mathrm{DQI}^{\mathrm{n}}$ \\
\hline $\mathrm{DBS}$ & $2.39^{* *}$ & $0.21^{* *}$ & $1.66^{\mathrm{ns}}$ & $1.11^{\mathrm{ns}}$ & $0.45^{\mathrm{ns}}$ & $17309.4^{* *}$ & $0.26^{*}$ & $1.81^{* *}$ & $0.004^{4 \mathrm{~s}}$ \\
$\mathrm{~S} 1$ & ${ }^{(1)} 8.52 \mathrm{a}$ & $1.20 \mathrm{~b}$ & 25.94 & 242.0 & 15.55 & $137.9 \mathrm{~b}$ & $1.94 \mathrm{~b}$ & $7.05 \mathrm{a}$ & 0.0535 \\
$\mathrm{~S} 2$ & $8.64 \mathrm{a}$ & $1.37 \mathrm{a}$ & 26.67 & 255.2 & 15.79 & $177.5 \mathrm{a}$ & $1.41 \mathrm{~b}$ & $6.21 \mathrm{a}$ & 0.0592 \\
$\mathrm{~S} 3$ & $5.75 \mathrm{~b}$ & $1.60 \mathrm{~b}$ & 22.29 & 263.4 & 15.62 & $134.1 \mathrm{~b}$ & $2.10 \mathrm{a}$ & $4.54 \mathrm{~b}$ & 0.0597 \\
$\mathrm{~N}$ & $0.53^{\mathrm{ns}}$ & $0.06^{\mathrm{ns}}$ & $4.81^{* *}$ & $62.42^{* *}$ & $69.06^{* *}$ & $22062.4^{* *}$ & $0.14^{*}$ & $0.18^{\mathrm{ns}}$ & $0.0010^{* *}$ \\
$\mathrm{DBS} \times \mathrm{N}$ & $1.04^{* *}$ & $0.01^{\mathrm{ns}}$ & $0.86^{\mathrm{ns}}$ & $16.95^{\mathrm{ns}}$ & $2.74^{\mathrm{ns}}$ & $845.45^{\mathrm{ns}}$ & $0.15^{* *}$ & $0.76^{* *}$ & $0.0001^{\text {ns }}$ \\
Error & 0.25 & 0.03 & 0.86 & 9.41 & 3.55 & 2129.45 & 0.05 & 0.15 & 0.0002 \\
$\mathrm{CV}(\%)$ & 17.44 & 13.56 & 18.52 & 43.75 & 12.04 & 30.79 & 13.96 & 15.09 & 27.05 \\
\hline
\end{tabular}

Note. ${ }^{(1)}$ Original averages. ${ }^{* *}$ : Significant at $1 \%$ probability. $*$ : Significant at $5 \%$ probability. ${ }^{\text {ns }}$ : Not significant. CV: Coefficient of variation. DBS: Decomposed buriti stem. N: Nitrogen rates. S1: 100\% soil + 0\% DBS. S2: 75\% soil $+25 \%$ DBS. S3: $50 \%$ soil $+50 \%$ DBS. ${ }^{(T)}$ : values transformed into $\sqrt{x+1}$ for analysis of variance.

For the plant height, shoot:root dry matter ratio and height:diameter ratio of cagaita seedlings, there was a significant difference between the substrates at the highest $\mathrm{N}$ application rates $\left(200,300\right.$ and $400 \mathrm{mg} \mathrm{dm}^{-3} \mathrm{of} \mathrm{N}$ ), where the substrate S3 resulted in lower plant height and height:diameter ratio (Table 3). In turn, the highest plant height and height:diameter ratio was obtained with the use of substrate S2 in association with the application of 200 and $300 \mathrm{mg} \mathrm{dm}^{-3}$ of $\mathrm{N}$, but did not differentiate from the substrate $\mathrm{S} 1$. 
Table 3. Effects of substrates formulated from different proportions of decomposed buriti stem (Mauritia flexuosa L.) and nitrogen application rates on plant height (PH), shoot:root dry matter ratio (SRR), and height:diameter ratio (HDR) of cagaita (Eugenia dysenterica DC.) seedlings

\begin{tabular}{|c|c|c|c|c|c|}
\hline \multirow{2}{*}{ Decomposed buriti stem (DBS) } & \multicolumn{5}{|c|}{ Nitrogen rates $\left(\mathrm{mg} \mathrm{dm}^{-3}\right)$} \\
\hline & 0 & 100 & 200 & 300 & 400 \\
\hline \multicolumn{6}{|l|}{ Plant height (cm) } \\
\hline S1: $100 \%$ Soil $+0 \%$ DBS & $5.17 \mathrm{a}$ & $7.33 \mathrm{a}$ & $7.97 \mathrm{ab}$ & $10.50 \mathrm{a}$ & $11.62 \mathrm{a}$ \\
\hline S2: $75 \%$ Soil + 25\% DBS & $6.75 \mathrm{a}$ & $9.75 \mathrm{a}$ & $11.00 \mathrm{a}$ & $10.97 \mathrm{a}$ & $4.68 \mathrm{~b}$ \\
\hline S3: $50 \%$ Soil $+50 \%$ DBS & $6.42 \mathrm{a}$ & $7.08 \mathrm{a}$ & $5.50 \mathrm{~b}$ & $4.75 \mathrm{~b}$ & $5.00 \mathrm{~b}$ \\
\hline \multicolumn{6}{|c|}{ Shoot:root dry matter ratio $\left(\mathrm{mg} \mathrm{mg}^{-1}\right)$} \\
\hline S1: $100 \%$ Soil + 0\% DBS & $1.54 \mathrm{a}$ & $1.51 \mathrm{a}$ & $1.70 \mathrm{~b}$ & $2.11 \mathrm{a}$ & $2.84 \mathrm{a}$ \\
\hline S2: $75 \%$ Soil + 25\% DBS & $1.08 \mathrm{a}$ & $1.39 \mathrm{a}$ & $1.60 \mathrm{~b}$ & $1.84 \mathrm{a}$ & $1.18 \mathrm{~b}$ \\
\hline S3: $50 \%$ Soil $+50 \%$ DBS & $1.37 \mathrm{a}$ & $2.70 \mathrm{a}$ & $3.11 \mathrm{a}$ & $1.92 \mathrm{a}$ & $1.42 \mathrm{~b}$ \\
\hline \multicolumn{6}{|l|}{ Height:diameter ratio $\left(\mathrm{cm} \mathrm{mm}^{-1}\right)$} \\
\hline S1: $100 \%$ Soil + 0\% DBS & $4.89 \mathrm{a}$ & $5.99 \mathrm{a}$ & $6.11 \mathrm{a}$ & $8.40 \mathrm{a}$ & $9.85 \mathrm{a}$ \\
\hline S2: $75 \%$ Soil + 25\% DBS & $5.18 \mathrm{a}$ & $6.84 \mathrm{a}$ & $7.61 \mathrm{a}$ & $7.82 \mathrm{a}$ & $3.60 \mathrm{~b}$ \\
\hline S3: $50 \%$ Soil $+50 \%$ DBS & $5.43 \mathrm{a}$ & $5.62 \mathrm{a}$ & $4.24 \mathrm{~b}$ & $3.61 \mathrm{~b}$ & $3.79 \mathrm{~b}$ \\
\hline
\end{tabular}

Note. Means followed by distinct letters in the column show significant differences by the Tukey test at the $5 \%$ probability level.

The plant height values as a function of the $\mathrm{N}$ application rates were adjusted to the linear polynomial regression model for the substrate S1, quadratic for S2 and cubic for S3 (Figure 1A). Without the use of N fertilizer, substrates S2 and S3 resulted in increased plant height of $20.2 \%$ and $21.8 \%$, respectively, when compared to substrate $\mathrm{S} 1$. With the increase of the $\mathrm{N}$ fertilizer rates, in the substrate $\mathrm{S} 2$ there was a maximum plant height increase of $80.4 \%$ with application of $190 \mathrm{mg} \mathrm{dm}^{-3}$ of $\mathrm{N}$. To obtain this same increase with the substrate $\mathrm{S} 1$ was necessary the application of $400 \mathrm{mg} \mathrm{dm}^{-3}$ of $\mathrm{N}$. For the substrate $\mathrm{S} 3$ there was a significant increase of the plant height due to the increase of the $\mathrm{N}$ fertilizer rates. 


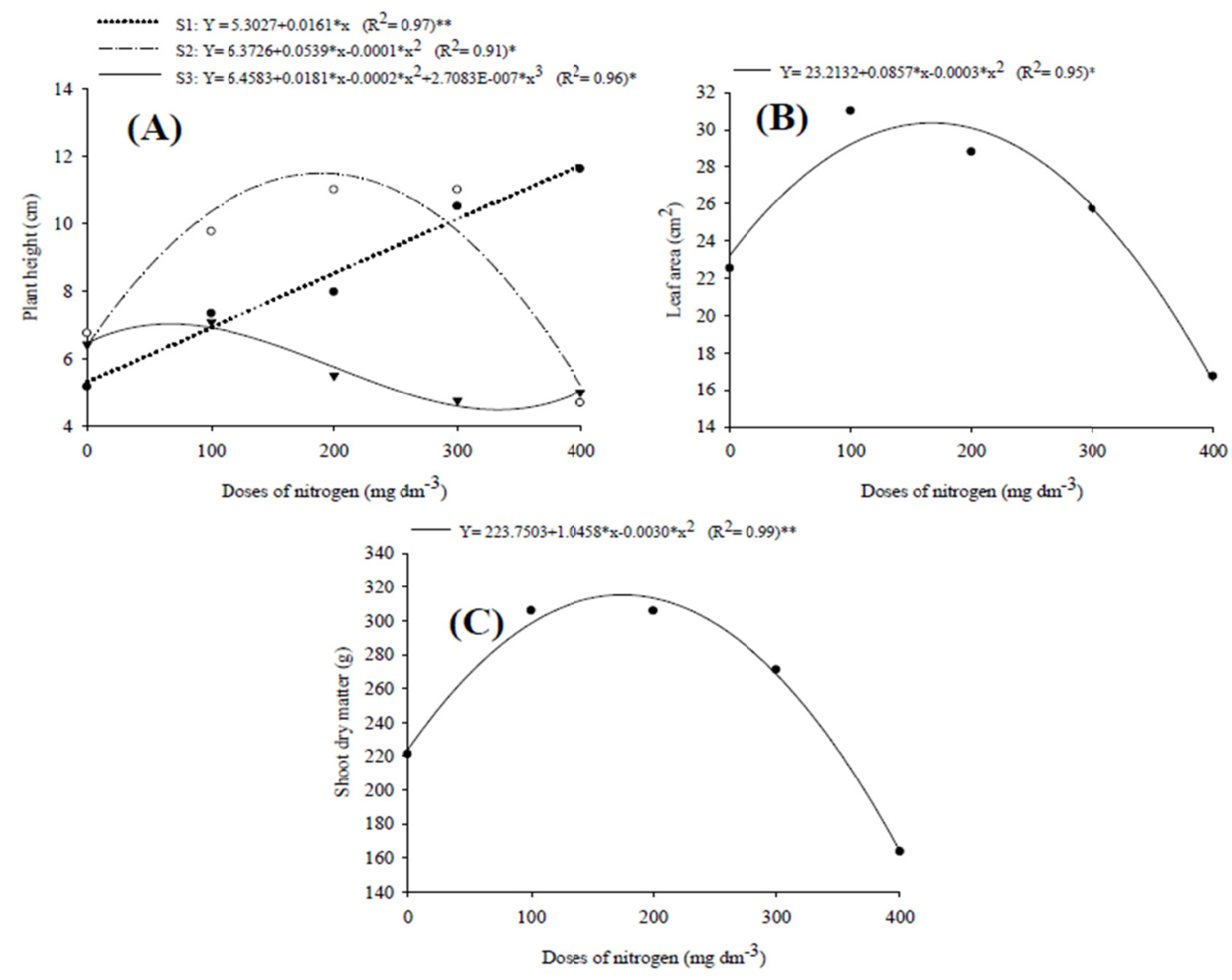

Figure 1. Effects of nitrogen application rates and substrate composition formulated with soil and decomposed buriti stem on plant height (A), leaf area (B), and shoot dry matter (C) of Eugenia dysenterica DC. seedlings. $*$ and $* *$ : Significant at $5 \%$ and $1 \%$ by the t-test, respectively

For the leaf area (Figure 1B) and shoot dry matter (Figure 1C) there was an adjustment of the quadratic polynomial regression model, with a positive effect of the $\mathrm{N}$ fertilizer rates. The maximum increase of these variables in $30.9 \%$ and $40.9 \%$ was observed with the rates of 167.33 and $174.88 \mathrm{mg} \mathrm{dm}^{-3}$ of $\mathrm{N}$, respectively. The application of $\mathrm{N}$ rates did not result in a positive effect on root length (Figure 2A) and root dry matter (Figure 2B).
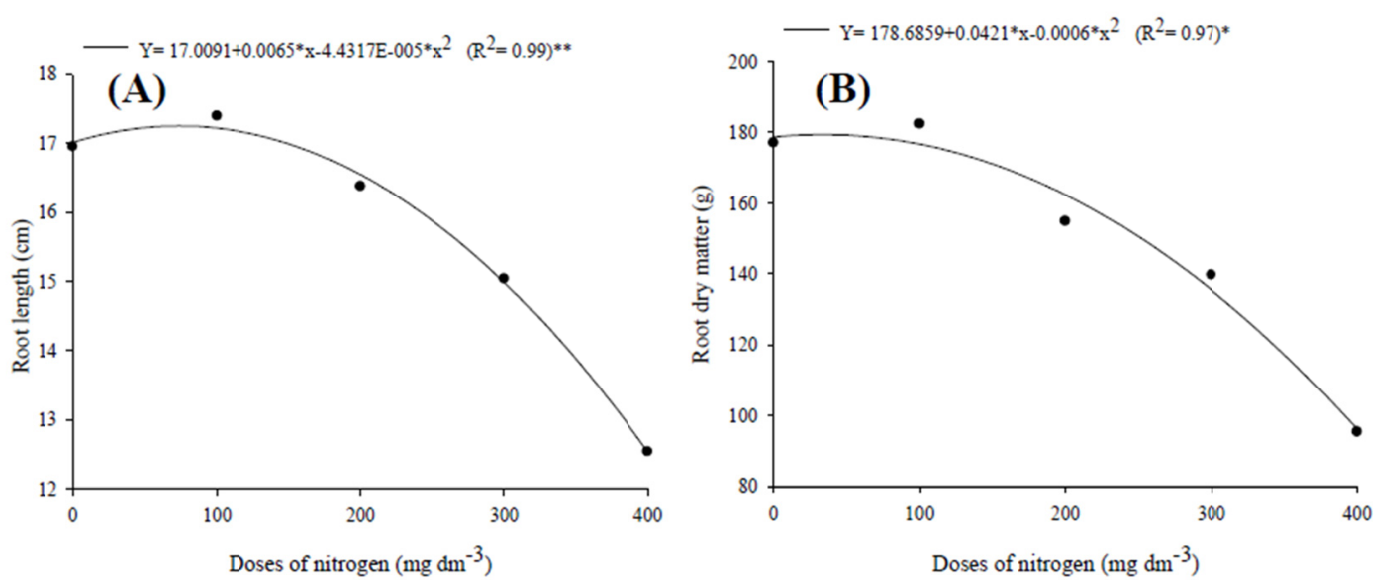

Figure 2. Effects of nitrogen application rates on root length (A) and root dry matter (B) of Eugenia dysenterica DC. seedlings. * and **: Significant at $5 \%$ and $1 \%$ by the t-test, respectively 
With the increase of the $\mathrm{N}$ rates, the shoot:root dry matter ratio (SRR) adjusted to the linear polynomial regression model for substrate S1 and quadratic regression for S2 and S3 (Figure 3A). The maximum SRR value of 2.85 (i.e., $91.5 \%$ increase) observed in the substrate $\mathrm{S} 3$ was obtained with application of $190.7 \mathrm{mg} \mathrm{dm}^{-3}$ of N. While to obtain this same increase in the substrate S1 was necessary the application of $400 \mathrm{mg} \mathrm{dm}^{-3}$ of N.
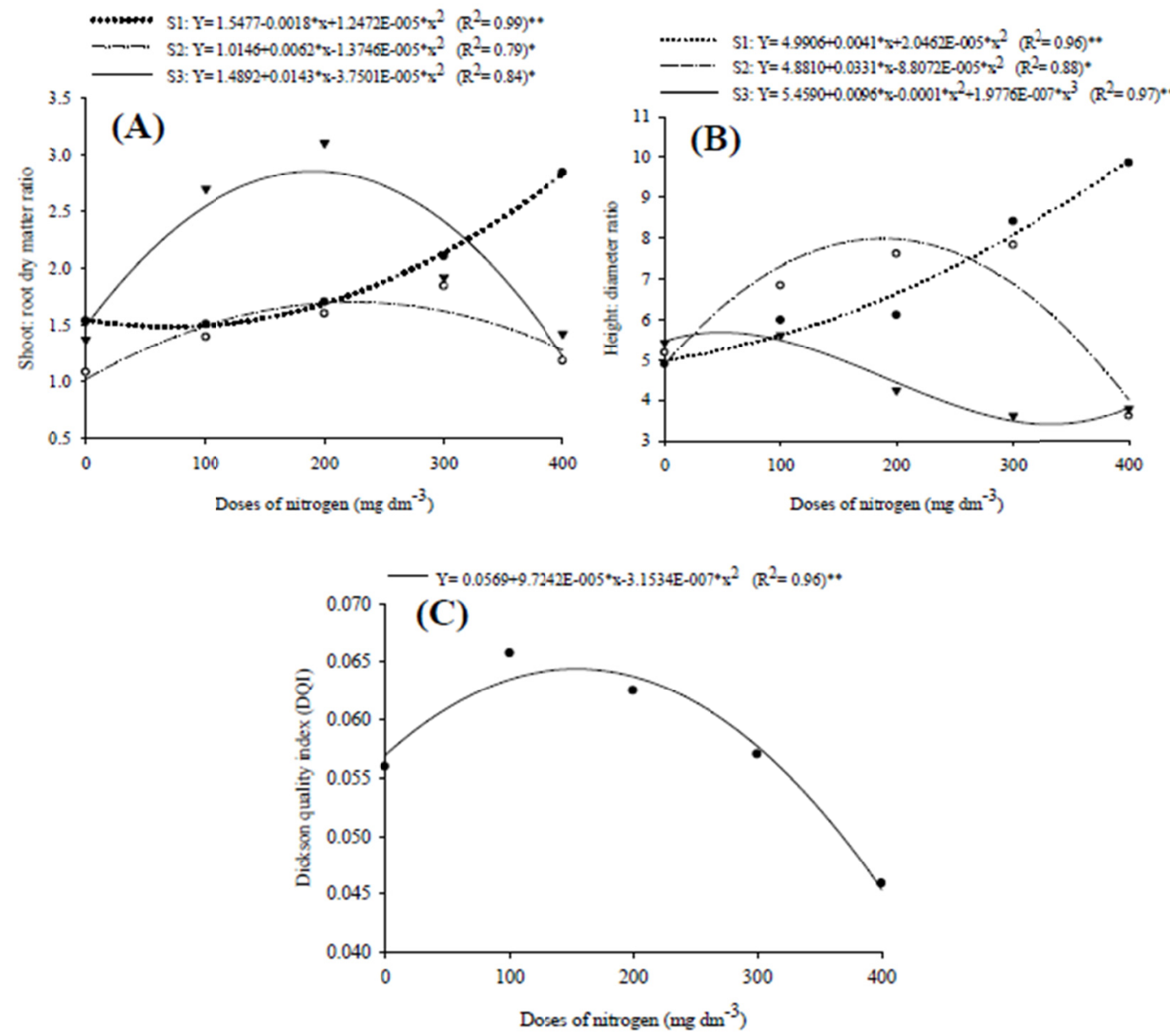

Figure 3. Effects of nitrogen application rates and substrate composition formulated with soil and decomposed buriti stem on the shoot:root dry matter ratio (A), height:diameter ratio (B), and Dickson quality index (C) of Eugenia dysenterica DC. seedlings. * and **: Significant at $5 \%$ and $1 \%$ by the t-test, respectively

For the height:diameter ratio (HDR), the increase of $\mathrm{N}$ application rates resulted in a linear, quadratic and cubic effect for the use of substrates S1, S2, and S3, respectively (Figure 3B). However, the combination of the substrate $\mathrm{S} 2$ with the rate of $187.9 \mathrm{mg} \mathrm{dm}^{-3}$ of $\mathrm{N}$ provided a maximum HDR value of 7.99 (i.e., $63.7 \%$ increase). While to obtain a similar or higher increase in the substrate S1 was necessary to apply rates higher than $300 \mathrm{mg}$ $\mathrm{dm}^{-3}$ of $\mathrm{N}$.

For the Dickson quality index (DQI), there was no significant difference between the different substrates (Figure 3C). However, the quadratic polynomial regression model was adjusted to the DQI values as a function of the $\mathrm{N}$ application rates. The maximum increase in DQI of $13.2 \%$ was obtained with the rate of $154.2 \mathrm{mg} \mathrm{dm}^{-3}$ of N.

\section{Discussion}

The results presented in the present study reported that the interaction between the substrates formulated with soil, DBS and nitrogen application rates are an important factor in the production of cagaita seedlings. The combination of the use of substrate formulated with $75 \%$ of soil $+25 \%$ of DBS with the application of 167.3 to $189.9 \mathrm{mg} \mathrm{dm}^{-3}$ of $\mathrm{N}$ contributed positively to the growth and development of shoots of the cagaita plants, as shown by higher plant height, stem diameter, leaf area, dry shoot matter, shoot:root dry matter ratio, height:diameter ratio and Dickson quality index. The combination of substrate formulated with $50 \%$ of soil $+50 \%$ 
of DBS and the application of $190.7 \mathrm{mg} \mathrm{dm}^{-3}$ of $\mathrm{N}$ contributed positively only to the increase of shoot:root dry matter ratio. Nitrogen is one of the most important nutrients for plants, being the essential constituent of amino acids, proteins, nitrogenous bases, nucleic acids, hormones, and chlorophyll, among other molecules necessary for the growth and development of plants (Costa et al., 2012; Silva et al., 2014). On the other hand, DBS is a substrate with high nutrient contents as previously reported by Amaral et al. (2010), which showed that the DBS had a $\mathrm{pH}$ of $6.8,0.31 \mathrm{mS} \mathrm{cm}^{-1}$ of electrical conductivity, $1.98 \mathrm{mg} \mathrm{L}^{-1}$ of nitrogen, $22.77 \mathrm{mg} \mathrm{L}^{-1}$ of potassium, $2.13 \mathrm{mg} \mathrm{L}^{-1}$ of calcium and $0.93 \mathrm{mg} \mathrm{L}^{-1}$ of magnesium. Therefore, the combination of the chemical characteristics of the substrate with $\mathrm{N}$ rates contributed to a greater growth of the plants and could, therefore, be a viable alternative to complement the nitrogen fertilization in the production of cagaita seedlings.

The DBS was successfully used in the formulation of substrates for the production of fruit plant seedlings such as gurgueia nut tree (Calvacante et al., 2011), passion fruit (Silva, 2012) and papaya (Albano et al. 2014), as well as for seedlings of tree species such as tamboril (Enterolobium contortisiliquum) (Sousa et al., 2013) and neem (Azadirachta indica) (Oliveira et al., 2016). In addition, the combination between substrates formulated with DBS in association with $\mathrm{N}$ rates was also evaluated by Oliveira et al. (2018) with satisfactory results in the development of amburana seedlings (Amburana cearensis).

In the development of the root system, there was a positive effect of the substrate formulated with $75 \%$ soil + $25 \%$ DBS in the increase of root dry matter. The DBS has the following physical characteristics: aeration space $(35 \%)$, wet density $\left(625 \mathrm{~kg} \mathrm{~m}^{-3}\right)$, dry density $\left(124 \mathrm{~kg} \mathrm{~m}^{-3}\right)$, water retention capacity $(57 \%)$ and pore volume (93\%). These characteristics, especially the aeration space, can favor the development of the root system since substrates with greater aeration space have a higher root volume than substrates with less aeration (Avelino et al., 2010; Silva Júnior et al., 2014).

\section{Conclusions}

The substrate containing soil and decomposed buriti stem in the proportion of 3:1 (v:v), in association with the application of $\mathrm{N}$ rates from 167 to $190 \mathrm{mg} \mathrm{dm}^{-3}$ is recommended for the production of cagaita seedlings, resulting in positive effects on plant growth and development as reported by higher plant height, shoot:root dry matter ratio and height:diameter ratio. The application of $154 \mathrm{mg} \mathrm{dm}^{-3}$ of $\mathrm{N}$ resulted in higher Dickson quality index of the cagaita seedlings.

\section{References}

Abadio Finco, F. D. B., Silva, I. G., \& Oliveira, R. B. (2012). Physicochemical characteristics and antioxidant activity of three native fruits from Brazilian savannah (Cerrado). Alimentos e Nutrição, 23(2), 179-185.

Agostini-Costa, T. S., Faria, J. P., Naves, R. V., \& Vieira, R. F. (2006). Frutas Nativas da Região Centro-Oeste do Brasil (1st ed., pp. 131-151). Brasília: Embrapa Recursos Genéticos e Biotecnologia Brasília.

Alves, A. S., Oliveira, L. S., Andrade, L. A., Gonçalves, G. S., \& Silva, J. M. (2012). Produção de mudas de angico em diferentes tamanhos de recipientes e composições de substratos. Revista Verde, 7(2), 39-44.

Amaral, G. C., Brito, L. P. S. B., Avelino, R. C., Júnior, V. S., Cavalcante, I. H. L., \& Cavalcante. M. Z. B. (2010). Caracterização Química de Potenciais Substratos Formulados a Partir de Materiais Regionais no Piauí (pp. 15-18). VII ENSub, September 2010, Anais... Goiânia, Goiás, Brazil.

Avelino, R. C., Brito, L. P. S. B., Júnior, V. S., Amaral, G. C., Cavalcante, I. H. L., \& Cavalcante. M. Z. B. (2010). Caracterização Física de Materiais Regionais Como Substratos Para a Produção de Mudas (pp. 15-18). VII ENSub, September 2010, Goiânia, Goiás, Brazil.

Brack, P., Kinupp, V. F., \& Sobral, M. E. G. (2007). Levantamento preliminar de espécies frutíferas de árvores e arbustos nativos com uso atual ou potencial no Rio Grande do Sul. Resumos do II Congresso Brasileiro de Agroecologia. Revista Brasileira Agroecologia, 2(1), 1769-1770.

Cavalcante, Í. H. L., Rocha, L. F., Silva Junior, G. B., Falcão Neto, R., \& Silva, R. R. S. (2011). Seedling production of gurguéia nut (Dypterix lacunifera Ducke) I: Seed germination and suitable substrates for seedlings. International Journal of Plant Production, 5(4), 319-322. https://doi.org/10.22069/IJPP.2012.743

Costa, M. S., Alves, S. M. C., Ferreira Neto, M., Batista, R. O., Costa, L. L. B., \& Oliveira, W. M. (2012). Produção de mudas de timbaúba sob diferentes concentrações de efluente doméstico tratado. Irriga, 1(1), 408-422. https://doi.org/10.15809/irriga.2012v1n01p408

Martinotto, C., Paiva, R., Santos, B. R., Soares, F. B., Nogueira, R. C., \& Silva, A. A. N. (2008). Efeito da escarificação e luminosidade na germinação in vitro de sementes de cagaiteira (Eugenia dysenterica DC.). Ciência e Agrotecnologia, 31(6), 668-1671. https://doi.org/10.1590/s1413-70542007000600010 
Martinotto, C., Paiva, R., Santos, B. R., Soares, F. P., Nogueira, R. C., Mendonça, R. C. de, ... Nogueira, P. E. (1998). Flora vascular do Cerrado. In S. M. Sano, \& S. P. Almeida (Ed.), Cerrado: Ambiente e flora; Planaltina: Embrapa Cerrados (pp. 289-556). Brasília.

Mendonça, R. C., Felfili, J. M., Walter, B. M. T., Silva-Júnior, M. C., Rezende, A. B., Filgueiras, T. S., ... Fagg, C. W. (2008). Flora vascular do Bioma Cerrado (pp. 213-228).

Oliveira, A. M. O., Fonseca, W. L., Sousa, T. O., Teixeira, H. R. S., Almeida, F. A., Zuffo, A. M., ... Santos, A. S. (2018). Initial growth of Amburana cearensis in decomposed buriti stem substrate and nitrogen doses. Journal of Agricultural Science, 10(7), 497-502. https://doi.org/10.5539/jas.v10n7p497

Oliveira, A. M., Fonseca, W. L., Heberle, E., Zuffo, A. M., Sousa, T. O., Almeida, F. A., ... Guerra, L. O. (2016). Organic substrates for neem seedlings production. International Journal of Current Research, 8(10), 39687-39692.

Sano, E. E., Rosa, R., Brito, J. L. S., \& Fereira, L. G. (2008). Mapeamento semidetalhado do uso da terra do bioma cerrado. Pesquisa Agropecuária Brasileira, 43(1), 153-156. https://doi.org/10.1590/s0100-204x2008 000100020

Sardinha, M. R. A. (2008). Manual do Viveiro Florestal (p. 70). Peru, Europam, Lda.

Silva Júnior, J. V., Beckmann-Cavalcante, M. Z., Brito, L. P. S., Avelino, R. C., \& Cavalcante, I. H. L. (2014). Aproveitamento de materiais alternativos na produção de mudas de tomateiro sob adubação foliar. Revista Ciência Agronômica, 45(3), 528-536. https://doi.org/10.1590/s1806-66902014000300013.

Silva RRS (2012). Substratos e boro para produção de mudas de maracujazeiro amarelo (Dissertação Mestrado em Solos e Nutrição de Plantas, Universidade Federal do Piauí, Bom Jesus).

Silva, C. P., Garcia, K. G. V., Tosta, M. S., Cunha, C. S. M., \& Nascimento, C. D. V. (2014). Adubação nitrogenada no crescimento inicial de mudas de jaqueira. Enciclopédia Biosfera, 10, 174-180.

Silva, R. S. M., Chaves, L. J., \& Naves, R. V. (2001). Caracterização de frutos e árvores de cagaita (Eugenia Dysenterica DC.) no sudeste do estado de Goiás, Brasil. Revista Brasileira de Fruticultura, 23(2), 330-334. https://doi.org/10.1590/s0100-29452001000200026

Silva, S. R. (2015). Sobrevivência e dados biométricos e fenológicos de plantas de cagaiteira Eugenia dysenterica (mart.) dc. Em fase inicial de desenvolvimento no campo 2015 (Dissertação Mestrado em Agronomia-Escola de Agronomia, Universidade Federal de Goiás, Goiânia).

Sousa, W. C., Brito, D. R. S., Amaral, F. H. C., Nóbrega, R. S. A., \& Nóbrega, J. C. A. (2010). Caracterização Química de Substratos Compostos de Pau de Buriti Para Cultivo de Mudas de Espécies Arbóreas (pp. 14-18) VII ENSub, September 2010, Goiânia, Goiás, Brazil.

Sousa, W. C., Nóbrega, R. S. A., Nóbrega, J. C. A., Brito, D. R. S., \& Moreira, F. M. S. (2013). Fontes de nitrogênio e caule decomposto de Mauritia flexuosa na nodulação e crescimento de Enterolobium contortsiliquum. Revista Árvore, 37(5), 969-979. https://doi.org/10.1590/S0100-67622013000500019

Souza, E. R. B. (2006). Fenologia, dados biométricos, nutrição de plantas e qualidade de frutos de cagaiteira (Eugenia dysenterica DC.) no estado de Goiás (Tese Doutorado em Agronomia, Escola de Agronomia, Universidade Federal de Goiás, Goiânia).

Souza, E. R. B., Carneiro, I. F., Naves, R. V., Borges, J. D., Leandro, W. M., \& Chaves, L. J. (2001). Emergência e crescimento de cagaita (Eugenia dysenterica DC.) em função do tipo e do volume de substratos. Pesquisa Agropecuária Tropical, 31(2), 89-95.

Viana, T. V. A., Vaconcelos, D. V., Azevedo, B. M., \& Souza, V. F. (2002). Estudo da aptidão agroclimática do Estado do Piauí para o cultivo da aceroleira. Ciência Agronômica, 33(2), 5-12.

\section{Copyrights}

Copyright for this article is retained by the author(s), with first publication rights granted to the journal.

This is an open-access article distributed under the terms and conditions of the Creative Commons Attribution license (http://creativecommons.org/licenses/by/4.0/). 